\title{
COMPARATIVE THERAPEUTIC FIELD TRIALS OF G.S. 2989 AND OXYTETRACYCLINE IN TRACHOMA* $\dagger$
}

\author{
BY \\ H. V. NEMA, K. NATH, A. BAL, O. P. JOSHI, AND B. R. SHUKLA \\ Trachoma Research Centre, Muslim University Institute of Ophthalmology, Aligarh, India
}

G.S. $2989 \mathrm{Hcl}$ (Pfizer) is a new tetracycline derivative without any generic name. In a clinico-cytological study by Nema, Nath, Bal, and Shukla (1964) on 48 trachomatous cases treated by G.S. $2989 \mathrm{Hcl}(0.25$ per cent. in oil) the antibiotic was found quite effective against trachoma and associated bacterial conjunctivitis. It was observed that the drug could produce 66.7 per cent. cure of trachoma after four weeks of continuous treatment. The following study was undertaken to judge the definite place and optimum concentration of G.S. 2989 in the mass treatment of trachoma.

\section{Materials and Methods}

A comparative intermittent topical therapeutic field trial was carried out at Alipur village (population 1,100) in the Aligarh district. The inhabitants constituted an ideal endemic sample of a trachomatous population in North India. In the months of October and November, 1962, all the children under 12 years of age were screened and 312 were found to be suffering from active trachoma (Expert Committee on Trachoma, 1962). The clinical findings of these cases were recorded on W.H.O. individual record cards. Selected trachomatous children were randomly divided into three identical groups (A, B, and C) in respect of stages of severity, gravity of trachoma, and its association with secondary bacterial conjunctivitis. Groups A and B were treated with 0.25 per cent. and 1.0 per cent. of G.S. 2989 in oil suspensions respectively; Group C received 1.0 per cent. oxytetracycline in oil. The intermittent schedule of treatment was followed in all the three groups. The drugs were instilled twice daily for five days in a month for six consecutive months. The treatment was started by a trained therapeutist in December, 1962, and ended in May, 1963.

All the treated cases of the three groups were re-examined in the last week of May, 1963, soon after the termination of treatment, and finally examined in September, 1963, four months later; 240 cases could be followed at the final assessment. Thus seventy-two children were excluded from this series because of their failure to receive planned treatment, or their absence at the first or final re-examinations.

\section{Results}

The incidence of associated secondary bacterial conjunctivitis was very high (145 out of 240 , or 60.4 per cent.) (Table I). For Groups A, B, and C, 74.7, 76.3, and

* Received for publication October 22, 1964.

$\dagger$ This trial was conducted under the guidance of Prof. B. R. Shukla, Officer-in-Charge, Trachoma Research Centre of the Indian Council of Medical Research. 
76.6 per cent. cure of trachoma was recorded respectively during treatment (Table II). After four months of follow-up the cure rate increased to $79 \cdot 5,88 \cdot 8$, and 77.9 per cent. (Table II). The effect of G.S. 2989 (0.25 per cent. and 1.0 per cent.) on the associated conjunctivitis was found to be more or less identical with oxytetracycline (1.0 per cent.) (Table III). However, G.S. 2989 (1.0 per cent.) was more effective in preventing the relapse and re-infection during the follow-up period (Table III).

TABLE I

Distribution of Active Trachoma Cases by Stage of Disease In Different Treatment Groups

\begin{tabular}{|c|c|c|c|c|c|c|c|c|c|c|}
\hline \multirow[t]{2}{*}{ Treatment Groups } & \multicolumn{2}{|c|}{$\begin{array}{l}\text { Total } \\
\text { Cases }\end{array}$} & \multicolumn{2}{|c|}{$\begin{array}{l}\text { Trachoma } \\
\text { I Cases }\end{array}$} & \multicolumn{2}{|c|}{$\begin{array}{l}\text { Trachoma } \\
\text { II Cases }\end{array}$} & \multicolumn{2}{|c|}{$\begin{array}{l}\text { Trachoma } \\
\text { III Cases }\end{array}$} & \multicolumn{2}{|c|}{$\begin{array}{c}\text { Associated } \\
\text { Conjunc- } \\
\text { tivitis } \\
\text { with active } \\
\text { Trachoma }\end{array}$} \\
\hline & No. & $\begin{array}{l}\text { Per } \\
\text { cent. }\end{array}$ & No. & $\begin{array}{l}\text { Per } \\
\text { cent. }\end{array}$ & No. & $\begin{array}{l}\text { Per } \\
\text { cent. }\end{array}$ & No. & $\begin{array}{l}\text { Per } \\
\text { cent. }\end{array}$ & No. & $\begin{array}{l}\text { Per } \\
\text { cent. }\end{array}$ \\
\hline $\begin{array}{l}\text { A (G.S. } 2989,0.25 \text { per cent.) } \\
\text { B (G.S. 2989, } 1.0 \text { per cent.) } \\
\text { C (Oxytetracycline, } 1.0 \text { per cent.) }\end{array}$ & $\begin{array}{l}83 \\
80 \\
77\end{array}$ & $\begin{array}{l}100 \cdot 0 \\
100 \cdot 0 \\
100 \cdot 0\end{array}$ & $\begin{array}{l}24 \\
19 \\
20\end{array}$ & $\begin{array}{l}28.9 \\
23 \cdot 8 \\
25.9\end{array}$ & $\begin{array}{l}27 \\
22 \\
23\end{array}$ & $\begin{array}{l}32 \cdot 5 \\
27 \cdot 5 \\
29.9\end{array}$ & $\begin{array}{l}32 \\
39 \\
34\end{array}$ & $\begin{array}{l}38 \cdot 6 \\
48 \cdot 8 \\
44 \cdot 2\end{array}$ & $\begin{array}{l}51 \\
45 \\
49\end{array}$ & $\begin{array}{l}61 \cdot 4 \\
56 \cdot 3 \\
63 \cdot 6\end{array}$ \\
\hline
\end{tabular}

TABLE II

Effect of Treatment on Trachoma In Three Treated Groups

\begin{tabular}{|c|c|c|c|c|c|c|c|c|}
\hline \multirow[t]{2}{*}{ Treatment Groups } & \multicolumn{2}{|c|}{$\begin{array}{c}\text { Total } \\
\text { Active } \\
\text { Cases } \\
\text { Treated }\end{array}$} & \multicolumn{2}{|c|}{$\begin{array}{c}\text { Cases } \\
\text { Cured } \\
\text { During } \\
\text { Treatment }\end{array}$} & \multicolumn{2}{|c|}{$\begin{array}{c}\text { Cases } \\
\text { Cured } \\
\text { During } \\
\text { Treatment } \\
\text { and } \\
\text { Follow-up }\end{array}$} & \multicolumn{2}{|c|}{$\begin{array}{c}\text { Cases } \\
\text { Cured } \\
\text { During } \\
\text { Follow-up }\end{array}$} \\
\hline & No. & $\begin{array}{c}\text { Per } \\
\text { cent. }\end{array}$ & No. & $\begin{array}{l}\text { Per } \\
\text { cent. }\end{array}$ & No. & $\begin{array}{c}\text { Per } \\
\text { cent. }\end{array}$ & No. & $\begin{array}{c}\text { Per } \\
\text { cent. }\end{array}$ \\
\hline $\begin{array}{l}\text { A (G.S. } 2989,0.25 \text { per cent.) } \\
\text { B (G.S. 2989, } 1.0 \text { per cent.) } \\
\text { C (Oxytetracycline, } 1.0 \text { per cent.) }\end{array}$ & $\begin{array}{l}83 \\
80 \\
77\end{array}$ & $\begin{array}{l}100 \cdot 0 \\
100 \cdot 0 \\
100 \cdot 0\end{array}$ & $\begin{array}{l}62 \\
61 \\
59\end{array}$ & $\begin{array}{l}74 \cdot 7 \\
76 \cdot 3 \\
76 \cdot 6\end{array}$ & $\begin{array}{l}66 \\
71 \\
60\end{array}$ & $\begin{array}{l}79 \cdot 5 \\
88 \cdot 8 \\
77 \cdot 9\end{array}$ & $\begin{array}{r}4 \\
10 \\
1\end{array}$ & $\begin{array}{r}4 \cdot 8 \\
12 \cdot 5 \\
1 \cdot 3\end{array}$ \\
\hline
\end{tabular}

TABLE III

Effect of Treatment on Associated Conjunctivitis in Three Treated Groups

\begin{tabular}{|c|c|c|c|c|c|c|c|c|c|c|}
\hline \multirow[t]{2}{*}{ Treatment Groups } & \multicolumn{2}{|c|}{$\begin{array}{c}\text { Total } \\
\text { Cases } \\
\text { Treated }\end{array}$} & \multicolumn{2}{|c|}{$\begin{array}{c}\text { Total } \\
\text { Cases } \\
\text { before } \\
\text { Treatment }\end{array}$} & \multicolumn{2}{|c|}{$\begin{array}{l}\text { Total } \\
\text { Cases } \\
\text { after } \\
\text { Treatment }\end{array}$} & \multicolumn{2}{|c|}{$\begin{array}{c}\text { Total } \\
\text { Cases } \\
\text { after } \\
\text { Follow-up }\end{array}$} & \multicolumn{2}{|c|}{$\begin{array}{c}\text { Cases with } \\
\text { Relapse or } \\
\text { Re-infection } \\
\text { during } \\
\text { Follow-up }\end{array}$} \\
\hline & No. & $\begin{array}{c}\text { Per } \\
\text { cent. }\end{array}$ & No. & $\begin{array}{l}\text { Per } \\
\text { cent. }\end{array}$ & No. & $\begin{array}{c}\text { Per } \\
\text { cent. }\end{array}$ & No. & $\begin{array}{c}\text { Per } \\
\text { cent. }\end{array}$ & No. & $\begin{array}{l}\text { Per } \\
\text { cent. }\end{array}$ \\
\hline $\begin{array}{l}\text { A (G.S. } 2989,0.25 \text { per cent.) } \\
\text { B (G.S. } 2989,1.0 \text { per cent.) } \\
\text { C (Oxytetracycline, } 1.0 \text { per cent.) }\end{array}$ & $\begin{array}{l}83 \\
80 \\
77\end{array}$ & $\begin{array}{l}100 \cdot 0 \\
100 \cdot 0 \\
100 \cdot 0\end{array}$ & $\begin{array}{l}51 \\
45 \\
49\end{array}$ & $\begin{array}{l}61 \cdot 4 \\
56 \cdot 3 \\
63 \cdot 6\end{array}$ & $\begin{array}{r}12 \\
13 \\
9\end{array}$ & $\begin{array}{l}14 \cdot 5 \\
16 \cdot 3 \\
11 \cdot 7\end{array}$ & $\begin{array}{l}32 \\
23 \\
30\end{array}$ & $\begin{array}{l}38 \cdot 6 \\
28 \cdot 8 \\
38 \cdot 9\end{array}$ & $\begin{array}{l}20 \\
10 \\
21\end{array}$ & $\begin{array}{l}24 \cdot 1 \\
12 \cdot 5 \\
27 \cdot 3\end{array}$ \\
\hline
\end{tabular}




\section{Discussion}

At present the sheet anchor of the mass campaigns being waged against trachoma and associated infections in endemic countries is the intermittent treatment by broadspectrum antibiotics. Encouraging results (with an accepted degree of failures) from the use of oxytetracycline and tetracycline have been reported from time to time (Bietti, 1951; Mitsui and Tanaka, 1951; Naccache, 1953; Pavkovic-Bugarski and Cvetojević, 1954; Tsutsui, 1959). However, clinical analysis of newer antibiotics is constantly being carried out in order to find a cheap, more effective, and easily acceptable drug for mass treatment. G.S. 2989 is definitely effective against trachoma and allied infections as is evident from Tables II and III. The cure rates in Groups A, B, and C were found to be $74 \cdot 7,76 \cdot 3$, and 76.6 per cent. respectively. G.S. $2989(0.25$ per cent.), G.S. 2989 ( 1.0 per cent.), and oxytetracycline ( 1.0 per cent.) did not show any significant difference one from the other $\left(\chi^{2}=0.02283\right.$ for 2 degrees of freedom). Differences in the three groups were re-tested taking two at a time. No group showed superiority over the other regarding the cure rate for trachoma.

Re-examination of cases after four months' cessation of treatment revealed an increase in cure rates in all the three groups (see Table II). This finding is contrary to our earlier observation (Nema and others, 1964) and is in agreement with the claims of Bietti (1955) and Maxwell-Lyons (1955), who recorded a higher cure rate of trachoma after three to four months of cessation of treatment. The probable explanation of this variation lies in the different treatment schedules adopted by the authors for the two trials. Moreover, in a mass campaign with overall coverage of active cases of trachoma, there are fewer chances of re-infection than in individual treatments, where the home and community produce active cases which may act as sources of re-infection. The percentage cure after four months in Group B was fairly high ( 88.8 per cent.), which significantly differed from Group C ( 77.9 per cent.). The cure rate in Group B compared with Group A was not statistically different. Thus it was inferred that G.S. $2989(0.25$ per cent. and 1.0 per cent.) and oxytetracycline ( 1.0 per cent.) were equally effective soon after treatment, but that G.S. 2989 (1.0 per cent.) was superior during the follow-up period.

Similarly, the drugs in all the three groups were found to be more or less equally effective against associated conjunctivitis at the cessation of treatment. Cases of relapse or re-infection were noticed at the final examination in all three groups, but the rate was comparatively low in the G.S. 2989 (1.0 per cent.) group. Therefore, it is concluded that G.S. 2989 ( 1.0 per cent. in oil suspension) is a useful drug in the therapy of trachoma and allied infections, particularly in checking the relapses of conjunctivitis.

\section{Summary}

A new antibiotic, G.S. $2989(0.25$ per cent. and 1.0 per cent. in oil suspension $)$ was evaluated against trachoma and allied infections in 240 trachomatous children. The drug was as effective as oxytetracycline at the cessation of treatment, but G.S. 2989 ( 1.0 per cent. in oil suspension) showed better results in the cure of trachoma, as well as in preventing the re-infection and relapses of associated conjunctivitis after four months of follow-up. 
We gratefully acknowledge the facilities provided by the Indian Council of Medical Research during this trial. G.S. 2989 was kindly supplied by Dr. K. G. S. Nanda of Messrs. Pfizer Ltd., Bombay.

\section{REFERENCES}

BietTI, G. B. (1951). W.H.O. Trachoma, 17, 1. (1955). Ibid., 39, 1.

Expert Committee on Trachoma (1962). Third Report. Wld Hlth Org. techn. Rep. Ser. No. 234, p. 15. MaXWell-Lyons, F. (1955). W.H.O. Trachoma, 65, 1.

Mitsui, Y., and TANAKA, C. (1951). Ibid., 2, 1.

NACCACHE, R. (1953). Brit. J. Ophthal., 37, 106.

Nema, H. V., Nath, K., Bal, A., and Shukla, B. R. (1964). Amer. J. Ophthal., 57, 747.

Pavkovic-Bugarski, G., and Cvetojević, M. (1954). Brit. J. Ophthal., 38, 692.

TsuTsui, J. (1959). Rev. int. Trachome, 36, 73. 